\title{
RESEARCH OF FORMATION EFFICIENCY INFORMATION AND COMMUNICATION COMPETENCIES IN SENIOR PUPILS OF THE SPECIAL COMPREHENSIVE SCHOOL
}

\author{
Tamara Sakhno \\ Postgraduate Student at the Department of Special Pedagogy and Inclusion, \\ Donbas State Pedagogical University, Ukraine \\ e-mail: t.s.sahno@gmail.com, orcid.org/0000-0003-2754-3286
}

\section{Wojciech Podlecki}

Professor, Ph.D., Polonia University in Czestochowa, Interdisciplinary Faculty, Poland e-mail: wpodlecki@ap.edu.pl,orcid.org/0000-0001-5645-2100

\section{Summary}

The article proposes special areas of work and identifies conditions for improving the effectiveness of the formation of these competencies in pupils, including high school. The research was conducted within the lessons of computer science, because they have a direct impact on the formation of information and communication competencies. It was found that the systematic and purposeful use of computer technology, special electronic correctional and developmental training programs and Internet services provides an opportunity to modernize and improve the quality of education, as well as pupils' interest in mastering basic computer science, to create a situation of success for each them. In the process of evaluating the effectiveness of the introduced areas of correctional and developmental education system, high school pupils were divided into two groups - control and experimental. The obtained data showed that the pupils of the control group did not experience significant changes in learning, while the pupils of the experimental group showed an improvement in performance in computer science lessons. Based on the results of the experimental study, it was found that the proposed correctional and developmental system of education is quite effective in increasing the level of formation of information and communication competencies in high school pupils with special needs. Prospects for further research are outlined.

Keywords: special education, children with special educational needs, computer science lessons, computer tools, information and communication competencies.

DOI https://doi.org/10.23856/4108

\section{Introduction}

In the new socio-economic conditions of society, there is an urgent need to prepare people for the rapid perception and processing of large amounts of information, mastering the relevant tools, methods and technology of working with information resources and computer technology. Accordingly, in these conditions, increase requirements for learning, knowledge and skills of pupils, to the level of their information competence. The use of modern information technologies makes it possible to modernize the educational process, improve the quality of education, pupils' interest in mastering basic knowledge, which significantly affects the formation of information and communication competencies in them.

For children of a special comprehensive school, mastering computer technology is especially important due to the significant difficulties they experience due to their disabilities. 
At the same time, without certain knowledge and skills in the field of computer science, it is impossible for such children to adapt to life in public space after graduation. Meanwhile, these skills are extremely necessary in the process of acquiring professional qualifications, because almost all modern tasks are solved with the participation of computer technology, and also have a direct solution to the socialization of senior pupils in general, the comfort life of persons of this category in the new socio-economic conditions. Thus, questions arise: to what extent working with a computer increases the efficiency of children, helps them focus and increases the pace of a number of educational tasks; how and to what extent to formation information and communication competencies in general in pupils with special needs.

Theoretical analysis of the researched problem shows that the difficulties of its solution are connected first of all with the state of education, uncertainty of pedagogical technologies and selection of appropriate methods and techniques of using e-learning tools, and practical work in a special school has not yet acquired a consistent systematic and holistic character. This state of development of the problem causes its insufficient effectiveness, encourages the search for effective pedagogical technologies for the formation of information and communication competencies in schoolchildren with special needs, which indicates the demand and relevance of the research.

The purpose of the article: to investigate the effectiveness of the formation of information and communication competencies in senior pupils of special comprehensive school in computer science lessons by implementing specially designed areas of correctional work.

Task of the research:

1. To study the state of the problem in the general and special psychological and pedagogical literature.

2. To develop directions of special correctional and developmental work aimed at the effective formation of information and communication competencies in senior pupils in computer science lessons.

3. Investigate the level of information and communication competencies in schoolchildren with special educational needs based on the introduced areas of correctional and developmental work.

\section{Methods of research:}

- theoretical - analysis, generalization, systematization of psychological and pedagogical literature on the problem of research, development of directions of formation of information and communication competencies in senior pupils of special comprehensive school;

- empirical - experimental - in order to identify the level of information and communication competencies in senior pupils of special school;

- data processing methods - to determine the statistical significance of the results obtained during the experiment.

\section{Analysis of recent research and publications}

Information and communication competencies are included in the list of key in the main strategic international documents, are cross-cutting, multifunctional, can be applied in various spheres of life (Hutmacher, 1997). They are considered, on the one hand, as a component of professional competence, and on the other - as a component of information culture. Among the significant features include knowledge of computer science as a subject, the use of computer as a necessary technical tool, motivation of subjects of educational space, a set of knowledge, skills and abilities to search, analyze and use information, data and knowledge, a positive attitude to information activities, the presence of an actual educational or professional task, in which information and communication competencies are formed (Holovan, 2007: 314-324). 
Theoretical and methodological approaches to the use of information and communication technologies (ICT) are described in the works of domestic and foreign scientists (M. Antonchenko, V. Baidenko, O. Kachurovska (Kachurovska, 2006: 46-49), O. Lehkii (Lehkii, 2001), S. Mironova (Mironova, 2003: 41-45), N. Savinova (Savinova, 2015), S. Patty (Patty, Borah, Herschman, 2001), J. Raven et al.), who emphasize that computer technology promotes the development of mental processes in children with special needs, their personality in general, increase quality of education. V. Zasenko, A. Kolupaieva, V. Larinets, S. Mironova (Mironova, 2003: 41-45), I. Tatianchikova (Tatianchikova, Sakhno, 2019: 91-94), M. Sheremet (Sheremet, 2001: 183-192) et al. are determining the role and place of ICT in the system of special education and proving the feasibility of using these technologies during training in special institutions for children with different nosology. O. Honcharova, O. Kukushkina, B. Moroz, V. Ovsianik, S. Trikoz (Trikoz, 2019: 99-100) et al. are outlining the importance and value of using the computer as a new tool for teaching and correcting defects in children with special educational needs; determining the place and role of the computer in various and individual lessons of such children. The positive effect of the use of computer technology on the motivation to teach pupils of special schools is described in the works of $\mathrm{V}$. Voronina, I. Kholkovskoi (Kholkovska, 2007), J. Bang, R. Gelman, E. Meck, R. Johanson et al. However, scientists claim that when introducing information and communication technologies in a special school, it is necessary to take into account the peculiarities of children's psyche, especially those that can complicate work with technology. This, in particular, increased fatigue, distracted attention, slower pace of perception, prolonged entry into the work process.

Psychological and pedagogical problems of using virtual computer environments, in particular the Internet, in the process of social rehabilitation and correctional media education of persons with special needs, advantages and risks of using the Internet environment as a form of rehabilitation space are presented in the works of V. Siniov, A. Shevtsov (Siniov, 2013: 89-99).

At the same time, all researchers point to the lack of special computer training programs for children with special educational needs as a negative fact.

As stated in one of UNESCO document, the current level of ICT development significantly expands opportunities for children with special educational needs. These technologies help to improve the functionality and efficiency management of learning tools, facilitating access to educational and professional information.

However, the analysis of the latest scientific publications and sources shows that the problem of using modern ICT tools in computer science lessons within a special comprehensive school is insufficiently developed. Today, pedagogical teams of special schools in Ukraine are on the way to solving the following questions: how and to what extent to use e-learning tools, forming ICTcompetencies in pupils with special needs; the extent to which working with a computer increases their ability to work, promotes concentration and increases the pace of a number of educational tasks.

\section{Areas of special correctional and developmental work}

The analysis of the researched problem gives grounds to assert that the correctly constructed strategy of formation of information and communication competences at senior pupils of special school should not be reduced to the simple list of those knowledge and skills, which pupils should master (knowledge of a computer device, skills with a text editor, the ability to search and find the necessary information on the Internet, etc.), although such knowledge and skills are really important to them. Meanwhile, the traditional way of learning does not ensure the successful transfer of skills from one situation to another. Schoolchildren master 
certain techniques of working on a computer, but they do not understand how these techniques should be combined to solve various practical problems. Real computer ownership involves more focused, creative, and flexible use of this powerful tool. Pupil must have a good idea of the ultimate goal, understand how to use a computer to solve various problems, and be able to actually use the basic technical devices and capabilities of e-learning tools. Each individual ICT skill, aimed at solving practical problems, acquires a completely different personal meaning for children with special needs. That is why the study proposes the following areas of work on the effective formation of information and communication competencies in senior pupils of special schools in computer science lessons (Fig. 1).

We believe that the central place in the formation of these competencies in children should be practice. It is important that they not only perceive the ready-made images given by the teacher, but also reproduce the given tasks on the computer in the process of drawing, printing text, calculations, etc.

In the practical work of pupils at the computer should use educational and developmental programs adapted to teach children with special educational needs. The distribution of time for the passage of material in the program, the order of study of topics and the number of hours allocated to them may vary slightly depending on the intellectual and psychophysical development of children. In a special school, information technology should not be seen as a subject of study, but as a tool for integrating the pupil into the modern world.

Of course, classes are not just about working at a computer. Schoolchildren can alternate writing exercises with computer ones, which will only increase their interest in the lessons and increase the efficiency of the lessons themselves.

In order to increase the efficiency of the formation of information and communication competencies in pupils of special schools in computer science lessons it is necessary to comply with the following conditions:

- the study of the material should be visual and multimedia, that is in the lessons in addition to the usual paper textbooks you need to use multimedia presentations (for example, using the program Microsoft PowerPoint);

- when performing some practical tasks, it is advisable to group pupils;

- to provide tasks for performance not only in paper, but also in electronic form that gives the chance to improve skills of possession of computer means at schoolchildren;

- actively apply the assembly in the lessons of a certain algorithm for the task, which will also help plan the actions of pupils in later life;

- special attention should be paid to enriching children's vocabulary with special computer terms, new words and expressions;

- tasks in computer science should be given to pupils in a clearly defined system, which provides for their gradual complication, compliance with the stages of formation of mental actions;

- to attract in computer science classes exercises and games of a logical nature to solve everyday problems using a computer;

- creating a situation of success;

- the material on the basics of computer science, which is mastered by high schoolchildren with special needs, should be practically oriented, that is to solve the problem of social adaptation, integration of children, their socialization in general.

Special electronic correctional and developmental training programs and Internet services provide many opportunities for the formation of information and communication competencies in pupils with special needs. We suggest using the following: computer games («Steps to Informatics», «GCompris» etc.), training sites («Hour of Code»: https://hourofcode.com/ua/ru/learn; electronic 


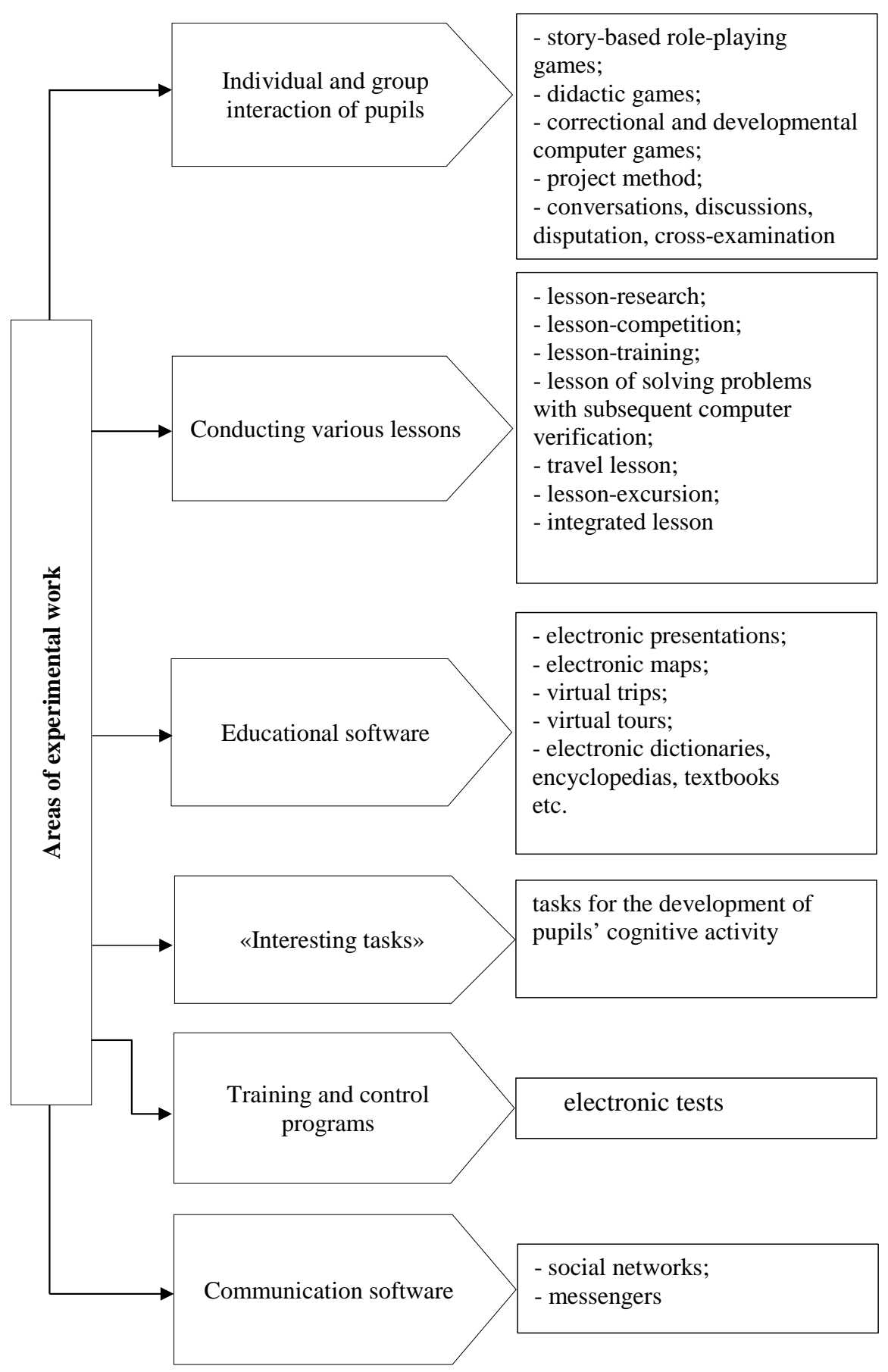

Fig. 1. Areas of work on the formation of information and communication competencies in pupils with special needs on computer science lessons 
maps Google Maps: https://www.google.com/maps/; virtual museum (for example, National Museum «Chernobyl»: http://chornobylmuseum.kiev.ua/uk/virtual-tour/); virtual trips (for example, a virtual tour of Ukrainian open-air museums: https://museums.authenticukraine.com.ua/ ua/, wooden churches of the Carpathian region of Ukraine: https://churches.authenticukraine.com. ua/ua/); electronic encyclopedias («Wikipedia»: https:/uk.wikipedia.org/wiki/, «Slovopedia»: http://slovopedia.org.ua/); electronic textbooks, dictionaries, translators, reference books, etc. and development services («LearningApps.org»: https://learningapps.org/, services for creating «tag clouds»: https://tagul.com/, http://www.imagechef.com/ etc.).

It is advisable to use a logical minute in each computer science lesson. It's obligatory elements are auditory tasks, visual elements, individual cards, solving crossword puzzles, riddles, assembling thematic puzzles. Such tasks can serve as motivation for the lesson (Timoshchiyk, Timoshkov, 2014: 11-13).

\section{The results of research}

To assess the effectiveness of the introduced areas of correctional and developmental education system, a study of the level of information and communication competencies of children - control and experimental groups. In this regard, were conducted sections of knowledge in the form of theoretical and practical tasks for knowledge of the basics computer science: the first control section was conducted at the end of the first semester, the second - at the end of the second semester (after the introduction of experimental methods) to compare the results of both groups. In total, the study covered 215 high schoolchildren from several special comprehensive schools. The first series of the experiment was conducted with pupils of 8th classes, the second series with pupils of 9 th classes, and the third series with pupils of 10 th classes.

The results of tasks (Table 1) were evaluated according to the general criteria for assessing the academic achievements of high schoolchildren at certain levels of academic success: high (10-12 points), sufficient (7-9 points), middle (4-6 points), low (1-3 points).

Table 1

Levels of performance of tasks on knowledge of bases computer science by pupils control and experimental groups (in \% of the total)

\begin{tabular}{|c|c|c|c|c|}
\hline \multirow{2}{*}{ Level } & \multicolumn{2}{|c|}{ Control group } & \multicolumn{2}{c|}{ Experimental group } \\
\cline { 2 - 5 } & $\begin{array}{c}\text { Before } \\
\text { the experiment }\end{array}$ & $\begin{array}{c}\text { After } \\
\text { the experiment }\end{array}$ & $\begin{array}{c}\text { Before } \\
\text { the experiment }\end{array}$ & $\begin{array}{c}\text { After } \\
\text { the experiment }\end{array}$ \\
\hline High & 4,7 & 4,5 & 5,7 & 9,3 \\
\hline Sufficient & 14,8 & 15,2 & 14,9 & 19,7 \\
\hline Middle & 38,0 & 37,0 & 38,1 & 44,8 \\
\hline Low & 42,6 & 43,5 & 41,9 & 26,1 \\
\hline
\end{tabular}

According to the tables, the pupils of the control group did not experience significant changes in learning. There was an almost slight decrease in the number of pupils with high (from $4,7 \%$ to $4,5 \%$ ), medium (from $38,0 \%$ to $37,0 \%$ ) and low (from $43.6 \%$ to $43.5 \%$ ) level of knowledge basics of computer science. The number of children with a sufficient level also increased slightly (from 14,8\% to 15,2\%). In general, the indicators of knowledge in children of the control group remain insufficient; they did not show positive dynamics (Fig. 2).

It is established that the improvement of these results is facilitated by the use of special correctional and developmental areas of work to increase the effectiveness of the formation of information and communication competencies in pupils with special needs. Thus, according 
to the table, in the experimental group the number of schoolchildren with high, sufficient and medium level increased (respectively: from 5,7\% to $9,3 \%$; from $14,9 \%$ to $19,7 \%$; from $38,1 \%$ to $44,8 \%$ ). There was also a significant decrease in the number of low-level pupils (from $41,9 \%$ to $26,1 \%$ ) after correctional and developmental classes (Fig. 3).

It should be noted that senior pupils who studied in the experimental program were less mistaken and were able to complete tasks even without the help of a teacher. In addition, they performed all the proposed tasks and exercises faster than the schoolchildren in the control group.

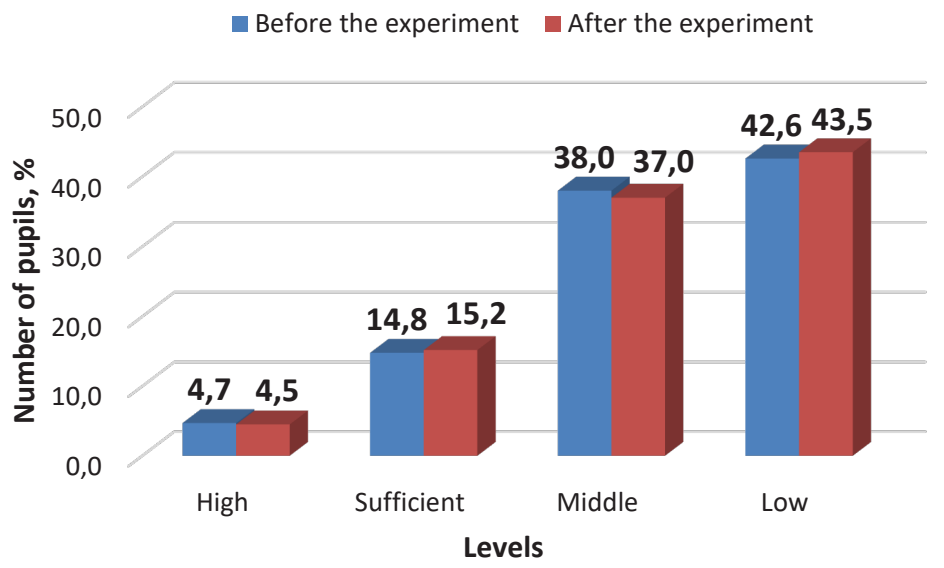

Fig. 2. The results of tasks performance for knowledge of the basics computer science by pupils of the control group before and after the experiment

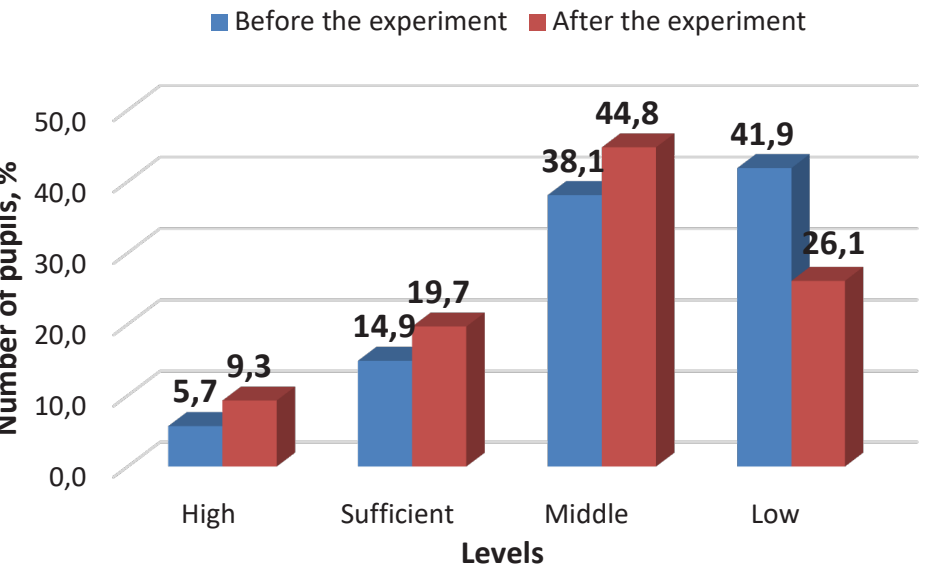

Fig. 3. The results of tasks performance for knowledge of the basics computer science by pupils of the experimental group before and after the experiment

The analysis of the results of our study showed that the pupils of the experimental group who participated in the training by a special method had significant advantages over the pupils of the control group, who did not participate in the experimental training, namely: 
- well and quickly mastered the general method of performing the proposed tasks, without experiencing significant difficulties;

- made significantly fewer mistakes when performing exercises during the experiment;

- the pupils of the experimental group did not refuse to perform the proposed tasks;

- the children of the experimental group needed less time to complete all tasks;

- the practical skills in computer science developed in the conditions of special correctional training have appeared much stronger and steady, and the received theoretical knowledge - more perfect and accurate;

- pupils of the experimental group used the acquired knowledge faster in practical exercises, when performing various tasks; were able to rely on this knowledge when playing situations from everyday life with the use of ICT.

The proposed experimental training provided an opportunity to create conditions for creative activity of high schoolchildren, to develop their initiative, independence and responsibility in the process of finding the right solution, to teach them to formulate and express their opinions, to lead a discussion, to use computer concepts. It should be noted that after special training the children of the experimental group became more active in computer science lessons, their interest and positive emotional state about the subject increased, which affected their level of learning and interaction with classmates. Therefore, in the process of conducting special purposeful and systematic corrective work it is possible to achieve in pupils with special needs the correct and conscious acquisition of knowledge in computer science, which significantly affects the increase efficiency of formation of their information and communication competencies.

\section{Conclusions}

The analysis of the research results showed that the effective formation of information and communication competencies in pupils of special schools requires the use of a special system of correctional and developmental work aimed at increasing computer literacy in children. Systematic and balanced use of ICT can be a powerful source of pupils' desire for knowledge, their satisfaction with the results of their own activities, the development of independent thinking, as well as the emergence of cognitive activity. It should be emphasized that the use of the proposed areas of work will be effective only if they are established on a permanent basis. The study can serve as a basis for further study of this issue, which involves improving the proposed system of work based on a deeper and multifactorial consideration of its components. Prospects for further research are to consider the use of information and communication competencies by graduates after graduating from a special school, development of new conceptual provisions for optimizing the preparation of these category children for independent living in modern digital space, taking into account the prospects of information and communication technologies in Ukraine.

\section{References}

Holovan M. (2007) Informatichna kompetentnist iak obiekt pedahohichnogo doslidzhennia [Information competence as an object of pedagogical research]. Problems of Engineering and Pedagogical Education, vol. 16, pp. 314-324.

Hutmacher W. (1997) Key competencies for Europe. A Secondary Education for Europe Project. Report of the Symposium Berne (Switzerland, Berne, March 27-30, 1996) Council for Cultural Cooperation, Strasbourg, France, 72 p.

Kachurovska O. (2006) Novitni zasobi korektsii ta rozvitku movlennia uchniv iz tiazhkimi vadami 
movi [Newest means of correction and development of pupils'speech with severe language defects]. Defectology, vol. 2, pp. 46-49.

Kholkovska I. L. (2007) Korektsiina pedahohika [Correctional pedagogy]. Vinnitsia: VDPU named M. Kotsubinskoho. [in Ukrainian]

Lekhkii O. M. (2001) Orhanizatsiino-pedahohichni umovi vikoristannia kompiutera u spetsialnii shkoli [Organizational and pedagogical conditions of using a computer in a special school] (PhD Thesis), Kyiv: Institute defectology APS of Ukraine.

Mironova S. (2003) Vikoristannia kompiutera u korektsiinomu navchanni ditei z vadami intelektu [Use of computer in correctional education of children with intellectual disabilities]. Defectology, vol. 3, pp. 41-45.

Organisation for Economic Co-operation and Development (2002) Definition and Selection of Competencies (DeSeCo): Theoretical and Conceptual Foundations. Strategy Paper. An Overarching Frame of Reference for a Coherent Assessment and Research Program on Key Competencies. Retrieved from: https://www.deseco. ch/bfs/deseco/en/index/02.parsys.34116.downloadList.87902.DownloadFile.tmp/ oecddesecostrategypaperdeelsaedcericd20029.pdf (accessed 07 July 2020).

Patty S. C., Borah E. G., Herschman J. (2001) UCLA Library Information Competence at UCLA: Report of a Survey Project. Retrieved from: https://escholarship.org/uc/item/4v06j4z5 (accessed 12 April 2020).

Savinova N. V. (2015) Informatsiino-komunikatsiini tekhnolohii v korektsiinii osviti [Information and communication technologies in correctional education]. Korektsiina pedahohika ta spetsialna psikholohiia (electronic journal), vol. 30, pp. 156-164. Retrieved from: http://enpuir.npu. edu.ua/bitstream/123456789/12014/1/ Savinova.pdf (accessed 09 June 2020).

Sheremet M. K. (2001) Suchasni kopiuterni tekhnolohii v lohopedichnii roboti [Modern computer technologies in logopedic work]. Pedahohika ta metodiki: spetsialni, vol. 1, pp. 183-192.

Siniov V. M. (2013) Potentsial virtualnoho kompiuternoho seredovischa v aspekti korektsiinoi mediaosviti $i$ sotsialnoi reabilitatsii osib z obmezhenniami zhittiediialnosti [The potential of the virtual computer environment in terms of corrective media education and social rehabilitation of people with disabilities]. Proceedings of the Mediaosvita v Ukraini: naukova refleksiia viklikiv, praktik, perspektiv (Ukraine, Kyiv, April 03, 2013) (eds. Siniov V. M., Shevtsov A. H.), Kyiv, pp. 89-99.

Tatianchikova I., Sakhno T. (2019) Formuvannia informatsiino-komunikatsiinikh kompetentnostei $v$ uchniv na urokakh informatiki [Formation of information and communication competencies in pupils at computer science classes]. Proceedings of the Tsifrova kompetentnist suchasnoho vchitelia novoi ukrainskoi shkoli (Ukraine, Kyiv, March 12, 2019) (eds. Ovcharuk O. V.), Kyiv: Institut informatsiinikh tekhnolohii i zasobiv navchannia NAPN Ukraini, pp. 91-94.

Timoshchiyk O., Timoshkov A. (2014) Metodichnii suprovid kursu «Skhodinki do Informatiki» [Methodical support of the course «Steps to Informatics»]. Informatika v shkoli (electronic journal), vol. 8, no. 68, pp. 11-13. Retrieved from: http://journal.osnova.com.ua/download/27-68-44739.pdf (accessed 08 April 2020).

Trikoz S. (2019) Vikoristannia kompiuternihk tekhnolohii u navchanni ditei z porushenniami intelektualnoho rozvitku [Use of computer technologies in teaching children with intellectual disabilities]. Proceedings of the Tsifrova kompetentnist suchasnoho vchitelia novoi ukrainskoi shkoli (Ukraine, Kyiv, March 12, 2019) (eds. Ovcharuk O. V.), Kyiv: Institut informatsiinikh tekhnolohii i zasobiv navchannia NAPN Ukraini, pp. 99-100.

UNESCO Institute for Information Technologies in Education (2006) ICTs in Education for People with Special Needs: specialized training course, Moscow: UNESCO Institute for Information Technologies in Education. Retrieved from: http://iite.unesco.org/pics/publications/en/ files/3214644.pdf(accessed 13 May 2020). 